\title{
Persepsi Guru tentang Keterampilan Koping untuk Mengelola Emosi Anak Usia 4-6 Tahun
}

\author{
Muthmainah $^{\bowtie}$ \\ Pendidikan Anak Usia Dini, Universitas Negeri Yogyakarta, Indonesia \\ DOI: $\underline{10.31004 / o b s e s i . v 6 i 3.1968}$
}

\begin{abstract}
Abstrak
Disregulasi emosi masih terjadi pada sebagian anak usia 4-6 tahun dan dapat menyebabkan kecemasan serta stres pada anak. Penelitian ini bertujuan untuk untuk mendeskripsikan persepsi guru tentang keterampilan koping untuk anak, pengetahuan awal guru tentang keterampilan koping, ketersediaan buku panduan keterampilan koping untuk anak, dan penerapan pengembangan keterampilan koping di kelas. Metode penelitian adalah survei dengan subyek penelitian yaitu 167 guru TK di wilayah Yogyakarta yang dipilih secara acak. Teknik pengumpulan data menggunakan angket dan dianalisis secara kuantitatif. Hasil penelitian menunjukkan 96\% guru menyatakan pentingnya keterampilan koping untuk anak, $87 \%$ guru belum mengetahui tentang keterampilan koping, 93\% guru menyatakan belum adanya buku panduan keterampilan koping, dan 54\% guru telah mengembangkan keterampilan koping di kelas melalui pembiasaan tetapi belum melalui pembelajaran. Hasil penelitian ini menegaskan perlu adanya pengembangan model pembelajaran dan buku panduan pembelajaran keterampilan koping untuk anak usia 4-6 tahun. Selanjutnya, para guru Taman Kanak-kanak perlu diberikan pelatihan agar semakin terampil dalam mengajarkan dan melatihkan keterampilan koping, sehingga anak mampu mengelola emosi dengan lebih baik.

Kata Kunci: emosi negatif; koping; anak usia 4-6 tahun
\end{abstract}

\begin{abstract}
Emotional dysregulation still occurs in some children aged 4-6 years and can cause anxiety and stress in children. This study aims to describe the teacher's perception of coping skills for children, the teacher's initial knowledge of coping skills, the availability of a coping skills guide book for children, and the application of developing coping skills in the classroom. The research method is a survey with research subjects, namely 167 kindergarten teachers in the Yogyakarta area who were randomly selected. The data collection technique used a questionnaire and analyzed quantitatively. The results showed that $96 \%$ of teachers stated the importance of coping skills for children, $87 \%$ of teachers did not know about coping skills, $93 \%$ of teachers stated that there was no coping skills manual, and $54 \%$ of teachers had developed coping skills in the classroom through habituation but not through learning. The results of this study confirm the need for the development of learning models and learning guidebooks for coping skills for children aged 4-6 years. Furthermore, kindergarten teachers need to be given training to become more skilled in teaching and practicing coping skills, so that children are able to manage emotions better.
\end{abstract}

Keywords: negative emotions; coping; children aged 4-6 years

Copyright (c) 2022 Muthmainah.

$\triangle$ Corresponding author :

Email Address : muthmainnah@uny.ac.id (Yogyakarta, Indonesia)

Received 18 October 2021, Accepted 9 January 2022, Published 15 January 2022 


\section{PENDAHULUAN}

Anak usia 4-6 tahun umumnya mengenyam pendidikan di Taman Kanak-kanak (TK). Masa tersebut merupakan masa transisi yang signifikan dalam kehidupan anak-anak, yang membawa tantangan dan harapan baru untuk mengelola perasaan sulit, membentuk hubungan baru, mengembangkan keterampilan dan pengetahuan akademik, mempelajari aturan, dan rutinitas kelas (O'Conner et al., 2017). Berdasarkan hasil wawancara dengan sepuluh guru TK di wilayah Sleman dan Bantul diperoleh informasi bahwa, tantangan sebagian anak TK saat ini antara lain tuntutan orangtua yang berlebihan, keinginan anak bermain bersama orangtua yang terhalangi oleh kesibukan orangtua, tekanan teman sebaya, merasa tidak aman dengan lingkungan, adanya kekerasan, dan tantangan lainnya. Tantangantantangan yang dialami dapat menimbulkan kecemasan dan membangkitkan emosi yang kuat.

Penelitian epidemiologis menunjukkan bahwa kesulitan perilaku, dan emosi sering dimulai pada usia dini dengan 5-15\% anak-anak (Taylor et al., 2020). Temuan-temuan tersebut diperkuat dengan hasil studi Graziano et al. (2007) yang mengungkapkan bahwa saat ini masalah emosional meningkat dimana sebagian anak mengalami gangguan kecemasan dan depresi, defisit dalam keterampilan menyelesaikan masalah (problem solving), dan prestasi akademik yang buruk. Permasalahan tersebut juga memiliki efek negatif pada kualitas hidup anak-anak, meningkatkan risiko berbagai masalah psikologis, fisik, dan sosial ekonomi, serta penyalahgunaan zat dan kenakalan di kemudian hari. Upaya untuk mengurangi risiko masalah kesehatan mental dan meningkatkan kesejahteraan psikologis pada usia awal, maka program pembelajaran emosional khususnya penyesuaian diri secara adaptif tampaknya diperlukan.

Kemampuan untuk menyesuaikan diri secara adaptif dengan stresor kehidupan adalah aset perkembangan yang penting. Temuan awal peneliti menunjukkan dari 154 anak, $62 \%$ anak masih menggunakan koping negatif (berteriak, tantrum, memukul, berkata kasar, dan perilaku negatif lainnya) saat mengalami emosi negatif. Fenomena inilah yang mendasari pentingnya anak dilatih koping agar lebih mampu mengelola emosi negatif. Penelitian yang dilakukan oleh (Chalmers et al., 2011) menyatakan bahwa anak-anak prasekolah dapat dilatih koping. Temuan (Frydenberg et al., 2014) menunjukkan anak-anak berusia empat tahun memiliki berbagai cara produktif dalam menghadapi situasi sulit. Anak-anak mampu menunjukkan kemampuan mengatasi masalah atau koping dengan mengubah strategi misalnya, dengan mengalihkan perhatian ke permainan lain, berbicara dengan dirinya sendiri (self talk), atau "memblokir" stimulus yang tidak menyenangkan contohnya dengan berpaling (Berk, 2006).

Koping dimaknai sebagai tindakan atau tanggapan terhadap situasi yang menantang untuk mencegah atau mengurangi marabahaya, kehilangan, bahaya, atau ancaman (Carver \& Connor-Smith, 2010). Koping bertujuan untuk mengatur rangsangan emosional, sedangkan tindakan koping bertujuan untuk mengatur pengalaman emosional internal, mengatur perilaku sebagai respon terhadap stresor, dan mengatur sumber rangsangan emosional. Ketika dihadapkan dengan stres, individu tidak hanya secara instan merespon, namun juga secara kognitif menilai situasi, dan kemudian berusaha untuk menghadapinya.

Penelitian (Compas et al., 2001) menunjukkan bahwa koping anak bervariasi, dan anak-anak yang memiliki keterampilan koping yang tinggi cenderung mampu menghadapi tantangan hidup yang penuh stres dengan cara yang lebih adaptif. Compas (2009) menambahkan bahwa, koping melatih anak mengekspresikan dan mengelola perasaan, mengatasi tuntutan-tuntutan dalam situasi yang menekan dan menegangkan, membantu anak untuk menerima situasi yang menekan, tidak merisaukan tekanan yang ada, dan mampu mengelola konflik, serta mengontrol stres yang berasal dari lingkungan sebagai upaya untuk beradaptasi. Perilaku adaptif anak di kelas termasuk dalam memilih koping dapat memprediksi kemampuan anak dalam berhubungan dengan teman, menerima tantangan tugas-tugas baru, dan menunjukkan kemampuan untuk menyelesaikan tugas yang diberikan 
(Mcdermott et al., 2019). Dalam membentuk perilaku adaptif anak tentunya diperlukan peran guru.

Guru yang memiliki persepsi tentang pentingnya suatu keterampilan tampak memiliki motivasi untuk memiliki keterampilan dan kompetensi tersebut agar mampu mengajar dengan lebih baik. Persepsi tersebut mendorong guru untuk meningkatkan kualitas praktik pembelajaran di kelas. Stresor yang teridentifikasi, kemampuan guru dalam melatih koping, serta rekomendasi dapat digunakan guru dan praktisi pendidikan lainnya (seperti psikolog sekolah dan konselor) untuk memfasilitasi dialog seputar kesejahteraan anak-anak untuk sekolah dan komunitas terkait (Sotardi, 2018). Para guru dapat melatih anak bagaimana mengatasi masalah atau menggunakan koping ketika menghadapi situasi yang penuh tekanan. Pernyataan tersebut diperkuat Durlak et al. (2011) yang menyatakan bahwa guru memainkan peran penting dalam pengembangan emosi anak-anak di bawah asuhannya. Guru dapat melatih anak agar memiliki keterampilan koping, dan mengekspresikan emosi secara tepat (Denham et al., 2012). Lebih lanjut, para guru dapat membantu anak-anak mengatasi (cope) masalah emosinya, sehingga anak-anak dapat mengevaluasi kembali pemikiran internalnya dan mendapatkan kepercayaan diri (Kong et al., 2012).

Temuan Gartrell \& Cairone (2014) menunjukkan bahwa guru yang mendorong dan merancang penggunaan keterampilan termasuk koping, dapat meningkatkan kemandirian dan menciptakan peluang positif untuk pertumbuhan anak. Dengan demikian, perkembangan emosi anak perlu menjadi perhatian dalam program anak usia dini (Dutta et al., 2014). Oleh karena itu, perlu untuk mengeksplorasi persepsi dan pengetahuan guru prasekolah tentang perilaku koping anak-anak ketika menghadapi situasi yang menantang dan penuh tekanan.

Yayasan Kesehatan Mental Anak melaporkan bahwa hasil pengamatan 46\% guru TK menunjukkan bahwa setidaknya satu setengah persen atau lebih anak tidak memiliki keterampilan koping yang diperlukan untuk kesiapan sekolah (Huffman, 2016). Lebih lanjut, Campbell \& Wiernik (2015) menambahkan bahwa anak-anak yang mengalami defisit keterampilan emosional dan kesehatan mental belum memperoleh intervensi. Fenomena yang terjadi menegaskan pentingnya peran sekolah dalam mencegah dan mengatasi permasalahan yang ada. Sekolah perlu membantu anak dalam mengembangkan kompetensi emosional, seperti keterampilan koping, kontrol diri, konsep diri yang positif, dan guru perlu menciptakan suasana kelas yang mendukung pengembangan kompetensi tersebut. Sekolah perlu mengembangkan sejumlah program kesehatan mental berbasis sekolah, termasuk mempromosikan keterampilan koping untuk mengurangi masalah perilaku dan emosi (Grewal et al., 2017).

Pada dasarnya pada jenjang Pendidikan Anak Usia Dini yaitu di Taman Kanak-kanak (TK) telah mengembangkan kompetensi emosi anak yang diatur dalam Kurikulum Tahun 2013. Apabila dicermati dalam kurikulum PAUD tahun 2013, kompetensi dasar yang berkaitan dengan keterampilan koping yaitu menunjukkan perilaku yang dapat menyesuaikan diri (SE 2.11), mengenali emosi diri dan orang lain serta mampu menunjukkan reaksi emosi diri secara wajar (3.13-4.13); dan mengenali dan mengungkapkan kebutuhan, keinginan, dan minat diri dengan cara yang tepat (3.14-4.14). Pada umumnya pengembangan keterampilan koping di TK lebih bersifat kuratif. Hasil wawancara dengan sepuluh guru menunjukkan bahwa anak diajari keterampilan koping setelah ada kejadian yang menimbulkan masalah. Kejadian tersebut seperti pertengkaran antar anak karena persaingan, saling mengejek, dan berebut mainan. Setelah kejadian berlangsung, guru baru memberikan nasehat bagaimana mengatasi masalah. Guru juga menyatakan belum adanya rencana program pembelajaran yang khusus membekali anak dengan materi koping.

Fakta lainnya yaitu sebagian sekolah lebih banyak menekankan pada bidang akademik atau aspek kognitif, serta penyiapan anak ke jenjang pendidikan formal berikutnya. Hal ini dibuktikan dalam penelitian Martani (2012) yang menunjukkan data bahwa, sebagian guru masih memiliki paradigma lama yang lebih memprioritaskan pada pengembangan kognitif 
dan kurang memperhatikan pengembangan emosional. Padahal pengembangan aspek kognitif perlu diimbangi dengan soft skill seperti keterampilan mepengelolaan diri, menghadapi tekanan, menunda kenikmatan, ketekunan menghadapi kejenuhan, atau kecenderungan membuat rencana (Beritagar, 2016). Pendapat tersebut dipertegas oleh Hansen \& Zambo (2007) yang menyatakan bahwa, apabila pendidikan di TK hanya memprioritaskan pada bidang akademik saja dan mengabaikan pengembangan emosi, maka anak akan kehilangan kesempatan untuk mengembangkan kemampuan emosi, termasuk keterampilan koping.

Pada penelitian sebelumnya diperkenalkan Child-Centered Play Therapy (CCPT) untuk melatihkan keterampilan koping pada anak. Lin \& Bratton (2015) menjelaskan bahwa CCPT merupakan teknik konseling yang menggunakan permainan sebagai bagian penting dalam terapi. Kegiatan lainnya yaitu bermain pura-pura yang diharapkan dapat meningkatkan kemampuan anak-anak dalam keterampilan koping melalui interaksi sosial (Hoffmann \& Russ, 2012). Pada umumnya, CCPT dan bermain pura-pura hanya diberikan bagi anak-anak yang memerlukan terapi tertentu dan di luar kegiatan pembelajaran di kelas. Selain itu, dalam kegiatan tersebut belum melibatkan orang tua. Faktanya, di Indonesia pada umumnya, terapi atau pembelajaran yang memfokuskan pada keterampilan koping untuk anak di Taman Kanak-kanak belum dilakukan. Mengingat pentingnya keterampilan koping untuk anak, maka guru sebagai pendidik sekaligus pengajar perlu menguasai konsep dan praktik pembelajaran keterampilan koping untuk anak sehingga dapat membekali anak agar mampu mengelola emosi dengan lebih baik. Selain itu, sejauh ini belum ada penelitian yang dilakukan untuk mengetahui kemampuan guru terkait keterampilan koping untuk anak.

Berdasarkan permasalahan yang ada, penelitian ini mendeskripsikan persepsi guru tentang keterampilan koping untuk anak, pengetahuan awal guru tentang keterampilan koping, ketersediaan buku panduan keterampilan koping untuk anak, dan penerapan pengembangan keterampilan koping di kelas untuk anak usia 4-6 tahun. Penelitian ini penting dilakukan untuk mengetahui urgensi keterampilan koping untuk anak usia 4-6 tahun. Selain itu, juga sebagai need assessment dan sebagai dasar untuk merancang model pembelajaran serta produk pendukung seperti buku panduan dan media pembelajaran yang perlu dikembangkan, sesuai dengan kebutuhan dalam mengajarkan dan melatihkan keterampilan koping untuk anak.

\section{METODOLOGI}

Penelitian kuantitatif ini menggunakan metode survei. Penelitian ini melibatkan 167 guru dari tiga kabupaten berbeda di Provinsi Yogyakarta (yaitu Sleman, Kota Yogyakarta, dan Bantul) dipilih secara acak. Teknik pengumpulan data yaitu dengan pemberian kuesioner dengan dua alternatif jawaban "penting" atau "tidak penting" untuk pertanyaan pertama, alternatif jawaban "mengetahui" atau "tidak mengetahui" untuk pertanyaan kedua, alternatif jawaban "ada" atau "belum ada" untuk pertanyaan ketiga, dan alternatif jawaban "sudah" atau "belum" untuk pertanyaan keempat. Item pernyataan dalam kuesioner disusun sesuai tujuan penelitian, yang didasarkan pada studi kepustakaan dan sudah melalui expert judgment. Penyebaran kuosioner dilakukan melalui pengisian google form. Selanjutnya data dipersentase dan dianalisis secara kuantitatif, yang selanjutnya digambarkan melalui histogram. Data hasil persentase dapat digunakan sebagai need assessment sebagai langkah awal yang dapat ditindaklanjuti dengan wawancara atau focused group discussion untuk merancang model pembelajaran dan produk pendukung pembelajaran keterampilan koping sesuai kebutuhan.

\section{HASIL DAN PEMBAHASAN}

Guru PAUD memiliki persepsi tentang pentingnya keterampilan koping untuk anak usia dini. Sejumlah 167 guru, 96\% menyatakan pentingnya keterampilan koping untuk anak. Adapun data terkait persepsi guru tentang pentingnya keterampilan koping untuk anak usia dini yang dapat dilihat pada Gambar 1 . 


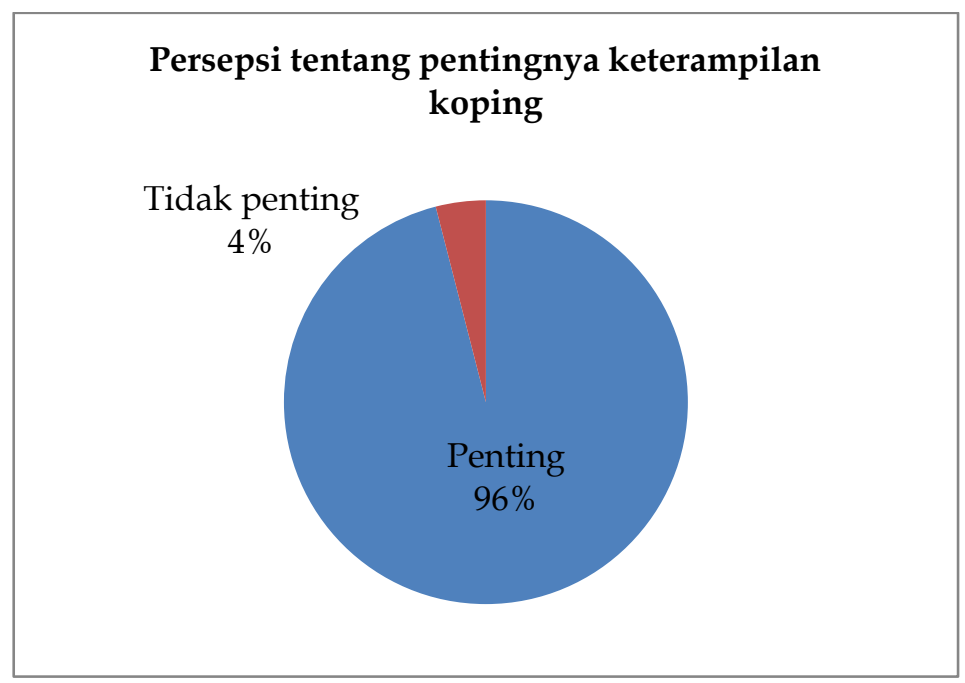

Gambar 1. Persepsi Guru tentang Pentingnya Keterampilan Koping untuk Anak Usia 4-6 Tahun

Berdasarkan Gambar 1 dapat dilihat bahwa dari 167 guru, 96\% menyatakan pentingnya keterampilan koping dikenalkan pada anak sejak dini. Hasil wawancara peneliti dengan lima guru TK menunjukkan bahwa anak perlu dibekali keterampilan koping karena tantangan dan kesulitan yang akan dihadapi anak semakin kompleks, sehingga perlu pengelolaan emosi yang baik. Kompleksitas masalah tersebut diantaranya terjadi karena kesibukan orang tua sehingga kurang memiliki waktu bersama dengan anak, pengasuhan orang tua yang kurang hangat, persaingan yang semakin ketat, adanya tugas sekolah yang semakin berat, serta pengaruh teman sebaya dan media sosial.

Selanjutnya, guru perlu memiliki pengetahuan sebelum mengajarkannya pada anak, termasuk terkait dengan keterampilan koping. Adapun data terkait pengetahuan guru terkait keterampilan koping untuk anak usia dini dapat dilihat pada Gambar 2.

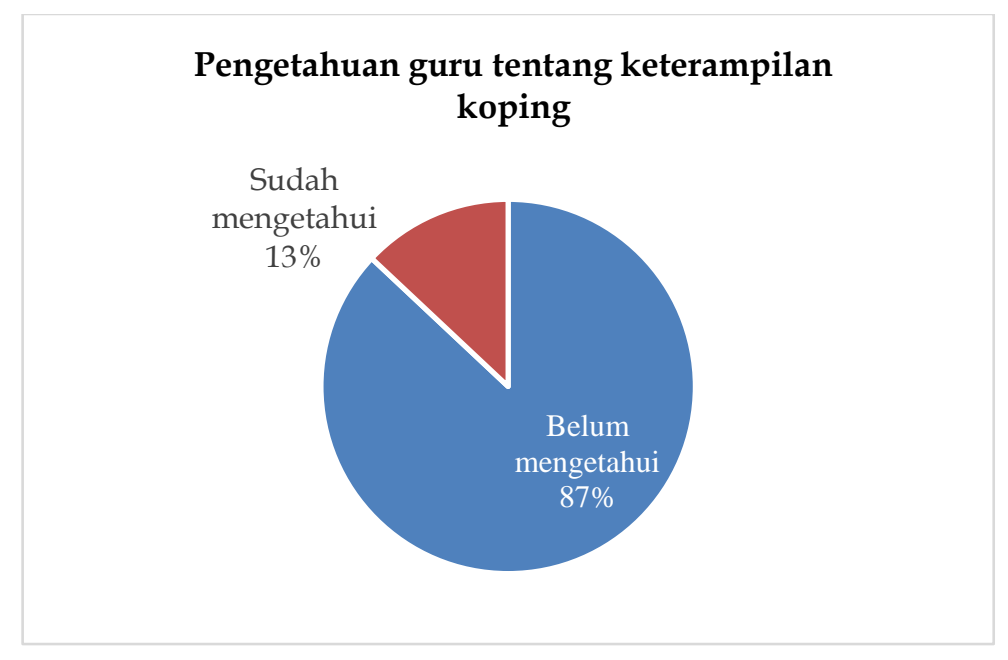

Gambar 2. Pengetahuan Guru tentang Keterampilan Koping

Gambar 2 menunjukkan bahwa dari 167 guru, 87\% guru menyatakan belum mengetahui tentang keterampilan koping. Sejumlah 13\% guru mengetahui keterampilan koping karena pernah mengikuti seminar terkait keterampilan anak dalam mengatasi masalah, memperoleh informasi dari psikolog sekolah, dan membaca dari buku atau media sosial. Hasil focused group discussion dan evaluasi peneliti dengan enam guru TK menunjukkan bahwa keterbatasan pengetahuan tentang keterampilan koping disebabkan belum adanya 
buku terkait koping, dan kegiatan pelatihan yang mengarah khusus pada pengembangan koping anak. Guru perlu dibekali dengan konsep koping dan pengembangannya, termasuk perangkat pembelajarannya. Dengan demikian, perlu adanya pelatihan agar para guru memiliki kompetensi untuk menerapkan materi koping dalam pembelajaran di kelas. Pembelajaran akan lebih efektif apabila guru telah menguasai pengetahuan dan keterampilan tentang koping (strategi mengatasi masalah), sehingga guru pun memiliki koping positif dalam menghadapi masalah. Guru tidak hanya berperan sebagai pengajar dan pendidik yang kompeten, namun menjadi panutan dan model bagi anak dalam menerapkan koping positif.

Panduan diperlukan untuk menjadi acuan dalam penerapan suatu kegiatan. Hasil survei dengan terkait ketersediaan panduan pengembangan keterampilan koping dapat dilihat pada Gambar 3.

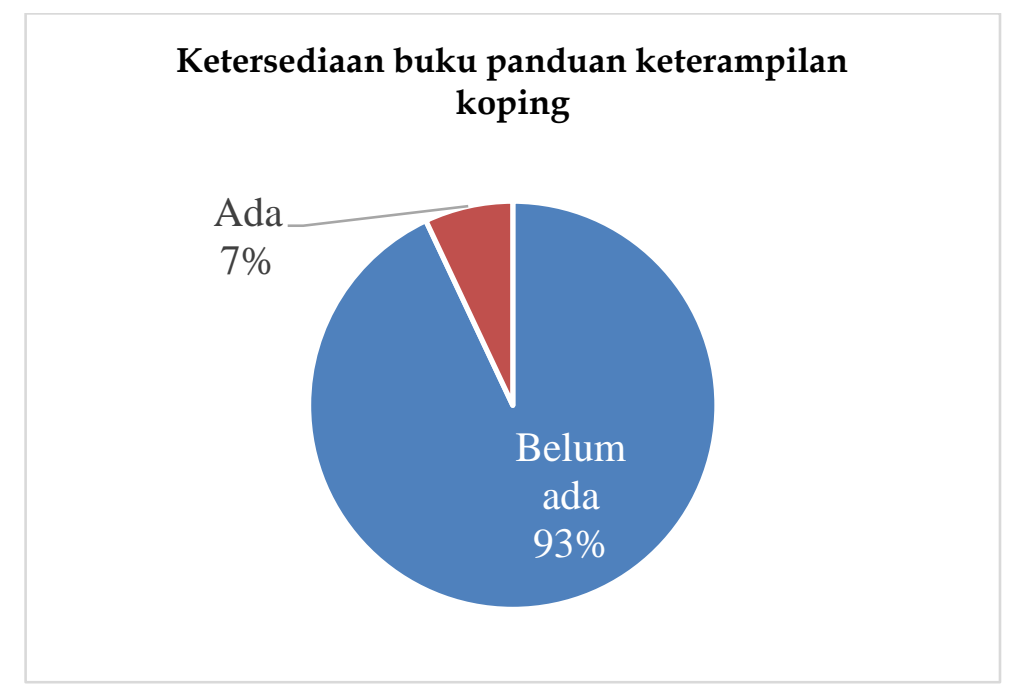

\section{Gambar 3. Ketersediaan Panduan Pengembangan Keterampilan Koping untuk Anak}

Gambar 3 menunjukkan bahwa dari 167 guru, 93\% guru belum menemukan buku panduan khusus yang memberikan informasi terkait pengembangan keterampilan koping untuk anak dalam pembelajaran di kelas. Sejumlah $7 \%$ menyatakan ketersediaan buku panduan sederhana yang disusun oleh pihak psikolog sekolah atau konsultan parenting. Berdasarkan hasil focus group discussion antara peneliti dan enam guru TK diperoleh data bahwa dalam buku panduan perlu adanya informasi terkait konsep keterampilan koping, ragam koping, dan teknis penerapannya dalam pembelajaran termasuk dalam pengembangan perangkat pembelajaran seperti Rencana Program Pembelajaran (RPP), bahan ajar, media, Lembar Kerja Peserta Didik (LKPD), serta instrumen pembelajaran. Selain buku panduan, para guru menyatakan perlunya sosialisasi terkait isi buku panduan.

Model keterampilan koping yang dikembangkan dalam pembelajaran di kelas dikaitkan dengan pengembangan sosial emosional yaitu pada Kompetensi Dasar 2.11 yaitu anak terbiasa memiliki perilaku yang dapat menyesuaikan diri, 3.13-4.13 yaitu anak mengenali emosi diri dan orang lain serta mampu menunjukkan reaksi emosi diri secara wajar, serta 3.14-4.14 yaitu anak mengenali dan mengungkapkan kebutuhan, keinginan, dan minat diri dengan cara yang tepat.

Keterampilan koping perlu diajarkan dan dilatihkan pada anak usia dini. Sebagian guru telah mengajarkannya di kelas, namun sebagian guru belum mengajarkannya di kelas. Adapun data penerapan pembelajaran koping di kelas dapat dilihat pada Gambar 4. 


\section{Penerapan pembelajaran keterampilan koping di kelas}

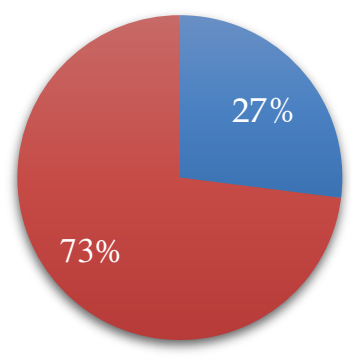

Sudah mengembangkan berbagai keterampilan koping di kelas

Belum mengembangkan berbagai keterampilan koping di kelas

\section{Gambar 4. Penerapan Pembelajaran Keterampilan Koping di Kelas}

Gambar 4 menunjukkan bahwa dari 167 guru, 27\% sudah menerapkan pembelajaran keterampilan koping di kelas meskipun baru bersifat kuratif, dan $73 \%$ belum menerapkan pembelajaran keterampilan koping di kelas karena belum adanya pengetahuan dan keterampilan untuk menerapkannya. Hasil wawancara dengan lima guru TK menyatakan bahwa penerapan pembelajaran keterampilan koping lebih banyak bersifat kuratif misalnya dengan menegur anak yang bertengkar, mengingatkan anak untuk tidak marah, berteriak atau menyakiti teman. Pemberian materi keterampilan koping yang bersifat preventif dan informatif belum diberikan pada anak di kelas.

Hasil focus group discussion dan evaluasi antara peneliti dan enam guru TK menunjukkan bahwa sejauh ini pengembangan sosial emosional di kelas belum spesifik mengarah pada materi keterampilan koping. Selanjutnya tindak lanjut evaluasi yaitu: 1) Pengembangan materi keterampilan koping perlu diarahkan sesuai Kurikulum 2013 khususnya pada pengembangan sosial emosional, 2) Pengembangan materi keterampilan koping dikaitkan dengan peranan emosi pada anak yaitu sebagai bentuk komunikasi dalam menyatakan keinginan atau perasaan, sehingga anak perlu dilatih mengkomunikasikan emosi dengan cara yang adaptif, 3) Pengembangan materi keterampilan koping idealnya berorientasi pada karakteristik perkembangan anak yang bermain sambil belajar, sehingga materi koping diterima anak dengan cara yang menyenangkan, 4) Pengembangan materi keterampilan koping sebaiknya disesuaikan dengan tahapan perkembangan kognitif anak yang berada pada tahap pra operasional, sehingga memerlukan media yang menarik dan metode pembelajaran untuk membantu anak berpikir konkrit, 5) Pengembangan materi keterampilan koping didasarkan pada pembelajaran bermakna yaitu dengan menentukan tujuan pembelajaran, karakteristik peserta didik (kemampuan awal, gaya belajar), dan memilih materi yang relevan dan dikaitkan dalam kehidupan sehari-hari anak, serta 6) Pengembangan materi keterampilan koping perlu dilengkapi dengan instrumen untuk menilai perkembangan keterampilan koping anak.

Berdasarkan hasil angket, wawancara, dan focus group discussion dapat disimpulkan bahwa perlu adanya model pengembangan pembelajaran keterampilan koping untuk anak. Melalui pembelajaran ini diharapkan anak akan memperoleh pengetahuan tentang keterampilan koping yang positif atau adaptif, dan kebiasaan menggunakan keterampilan koping positif untuk mengelola emosi negatif dalam kehidupan sehari-hari. Lebih lanjut, model pengembangan keterampilan koping perlu diintegrasikan ke dalam kurikulum sekolah. Alasan ini didasarkan pada pernyataan Masfuah \& Rusilowati (2011) bahwa hasil pendidikan bersifat jangka panjang, dimana dalam sekolah meliputi populasi yang cukup 
besar, dan masa sekolah merupakan masa yang tepat untuk menanamkan nilai-nilai pada peserta didik.

Anak-anak menghadapi permasalahan dan tantangan dalam kehidupan sehari-hari dan menggunakan koping yang berbeda. Temuan tersebut sejalan dengan hasil penelitian Frydenberg et al. (2014) yang menunjukkan bahwa, anak-anak memiliki berbagai cara produktif dalam menghadapi situasi sulit dengan pilihan koping masing-masing. Lebih lanjut Chalmers et al. (2011) juga menemukan bahwa anak-anak merespon emosi negatif dengan keterampilan koping yang produktif seperti melakukan sesuatu, mencoba menyelesaikan masalah, menangis, meminta bantuan, mencari ketenangan, dan bahkan ada yang merespon dengan pengelolaan emosi yang tidak produktif seperti merasa bingung dan akhirnya tidak melakukan apapun. Temuan tersebut, memperkuat temuan penelitian ini dimana guru menyatakan keterampilan koping penting untuk dilatihkan pada anak usia 4-6 tahun.

Hasil penelitian longitudinal dari Röll et al. (2012) menegaskan bahwa ketidakmampuan untuk menggunakan keterampilan mengatasi masalah merupakan faktor risiko dalam pembentukan perilaku agresif. Anak-anak yang memiliki masalah emosional dan perilaku berisiko lebih tinggi mengalami masalah di masa depan yang dapat mengganggu kehidupan, memengaruhi kesehatan mental, dan menimbulkan masalah perilaku yang dapat memengaruhi kemajuan akademik. Kesulitan-kesulitan tersebut juga memiliki efek negatif pada kualitas hidup anak-anak secara umum dan meningkatkan risiko berbagai masalah psikologis, fisik, dan sosial ekonomi, serta penyalahgunaan zat dan kenakalan di kemudian hari. Upaya yang dilakukan untuk mengurangi risiko masalah kesehatan mental dan meningkatkan kesejahteraan psikologis pada usia awal/dini, maka program pembelajaran emosional khususnya penyesuaian diri secara adaptif tampaknya diperlukan.

Di sekolah, peran pendidik prasekolah sangat penting, untuk mengidentifikasi dan mengelola bentuk-bentuk awal agresivitas yang merupakan salah satu mekanisme koping negatif atau maladaptif. Pelatihan bagi guru, pengkondisian lingkungan belajar yang positif serta penerapan strategi pencegahan dan intervensi perlu dilakukan (Douvlos, 2019). Abad 21 menghadirkan banyak tantangan baru bagi generasi muda. Untuk menghadapi tantangan ini, WHO (2015) melaporkan masalah kesehatan mental kaum muda yang meningkat pesat. Lebih lanjut, UNESCO (2019) merekomendasikan untuk menyebarluaskan program pembelajaran sosial emosional yang berpotensi mempengaruhi perkembangan generasi penerus dunia. Sekolah perlu mempromosikan pembelajaran sosial emosional melalui lingkungan belajar yang berpusat pada hubungan, metode pengajaran, dan penilaian formatif (Ferreira et al., 2020).

Guru memiliki peran besar dalam perkembangan keterampilan emosi anak, termasuk koping. Pernyataan tersebut diperkuat Durlak et al. (2011) yang menyatakan bahwa guru memainkan peran penting dalam pengembangan emosi anak-anak di bawah asuhannya. Guru berperan sebagai model koping positif saat pembelajaran di kelas maupun di luar pembelajaran. Hal ini sesuai dengan gagasan Dewantara (1977) yaitu bahwa pendidikan perlu menekankan pentingnya keteladanan atau percontohan orang dewasa. Orang dewasa harus memberikan contoh bertingkah laku yang baik sesuai dengan aturan yang berlaku di masyarakat.

Pengetahuan guru tentang keterampilan koping mendorong perannya sebagai fasilitator yang merancang kegiatan pembelajaran, perangkat pembelajaran, dan memfasilitasi penggunaan koping positif pada anak. Pernyataan ini diperkuat Kong et al. (2012) bahwa para guru dapat membantu anak-anak mengidentifikasi emosinya, sehingga anak-anak dapat mengevaluasi kembali pemikiran internalnya, memperoleh kepercayaan diri, serta mencapai keberhasilan di sekolah dan menjadi warga negara yang bertanggung jawab. Lebih lanjut para guru dapat melatih anak agar memiliki keterampilan koping, mengekspresikan emosi secara tepat dan melatih anak bagaimana mengelola emosi ketika menghadapi situasi yang penuh tekanan (Denham et al., 2012). Selain memfasilitasi anak-anak, guru juga perlu memfasilitasi orang tua. Guru berperan untuk memberikan edukasi pada orang tua, menyampaikan 
perkembangan anak, dan memberikan layanan konsultasi apabila orang tua meminta saran terkait permasalahan perilaku anaknya.

Santrock (2011) menyatakan bahwa, usia 5-12 tahun merupakan fase dimana seorang anak mengalami perkembangan emosi, kognisi, dan psikomotorik. Sebagai fasilitator, guru perlu menyampaikan materi pembelajaran dengan berbagai metode dan media. Salah satu bentuk pengembangannya adalah melalui pelibatan anak dalam proses pembelajaran di kelas. Pelibatan anak didik di dalam kelas adalah aktif dalam kegiatan bercakap-cakap, menyampaikan pendapat atau mengungkapkan perasaan, melakukan praktik, bermain peran, mengerjakan tugas, dan lainnya.

Sebagai motivator, guru perlu menjalin hubungan baik dengan anak-anak. Pernyataan tersebut sejalan dengan temuan Blazar \& Kraft (2017) yaitu bahwa guru perlu mendorong anak untuk menyampaikan perasaannya, menanyakan perasaan anak, menunjukkan empati, perhatian dan kepedulian terhadap anak-anak. Guru juga perlu meyakinkan anak agar jujur tentang perasaannya, dan tidak menabukan perasaan kebencian, sakit hati, dendam, kekerasan atau destruktif. Dombro et al. (2011) pun menegaskan bahwa untuk menciptakan hubungan yang positif dengan anak-anak, guru perlu dengan sengaja memberikan kesempatan dan latihan tersebut ke dalam kelas setiap harinya.

Ketersediaan buku panduan keterampilan koping untuk anak ternyata masih terbatas. Padahal buku panduan tersebut dapat membekali guru dalam merancang perangkat pembelajaran. Buku panduan juga berisi tentang berbagai metode pembelajaran yang interaktif yang perlu diterapkan guru. Selain itu, juga berisi tentang deskripsi berbagai media yang menarik dan pentingnya kehangatan guru agar membuat anak merasa nyaman dan senang. Hal ini sejalan dengan temuan Ho \& Funk (2018) bahwa perkembangan anak dapat dicapai dengan membacakan buku cerita pada anak-anak, mengajukan pertanyaan terbuka kepada anak-anak, memberikan penguatan positif spesifik, dan mencontohkan perilaku yang sesuai. Melalui kegiatan membacakan buku dengan suara keras kepada anak-anak dan mengajukan pertanyaan terbuka, banyak keterampilan sosial-emosional yang dapat dipraktikkan. Kegiatan rutin ini dilakukan agar anak-anak terbiasa menyampaikan pengalaman emosi atau pengalamannya sendiri yang berhubungan dengan buku. Buku anakanak adalah cara yang bagus untuk mendiskusikan emosi, teknik pemecahan masalah dan menghubungkannya dengan pengalaman anak-anak sendiri. Selain itu, perangkat pembelajaran seperti Rencana Program Pembelajaran (RPP), bahan ajar, media, LKPD, dan instrumen dalam pengembangan model ini menjadi hal penting.

Keterampilan koping perlu diterapkan di kelas baik melalui pembiasaan maupun dalam pembelajaran. Kelas anak usia dini memiliki peran penting dimana guru dapat berkontribusi dan antar anak dapat saling memengaruhi. Pernyataan ini sejalan dengan pendapat Bronfenbrenner (2004), bahwa kelas menjadi salah satu tempat dimana anak-anak dapat mengembangkan kemampuan emosional, termasuk cara mengatur pengalaman terkait emosi. Melalui iklim belajar yang menyenangkan, guru dapat mendukung perkembangan emosi anak. Temuan penelitian ini juga selaras dengan temuan Gartrell \& Cairone (2014) yang menyatakan bahwa guru yang mendorong dan merancang penggunaan keterampilan termasuk koping dalam interaksi sosial, terbukti dapat meningkatkan kemandirian dan menciptakan peluang positif bagi pertumbuhan anak. Anak-anak dapat saling memberikan pengaruh, ajakan, dan dorongan melalui interaksi sosial di kelas.

Hasil penelitian ini merupakan need assesment yang berkaitan dengan kemampuan guru dalam mengembangkan keterampilan koping untuk mengelola emosi anak usia 4-6 tahun. Dengan demikian, hasil penelitian ini perlu ditindaklanjuti dengan penelitian pengembangan model pembelajaran keterampilan koping untuk anak. Selain itu, pelatihan bagi para guru Taman Kanak-kanak agar dapat mengajarkan dan melatihkan keterampilan koping melalui pembelajaran di kelas juga menjadi komponen penting. Penelitian ini hanya menggunakan kuosioner dalam bentuk google form, sehingga perlu digali lebih mendalam dengan wawancara dan focused group discussion agar diperoleh informasi yang lebih 
komprehensif dalam pengembangan model pembelajaran keterampilan koping yang tepat untuk anak usia 4-6 tahun.

\section{SIMPULAN}

Hasil penelitian menunjukkan 96\% guru menyatakan pentingnya keterampilan koping untuk anak, 87\% guru belum mengetahui tentang keterampilan koping, 93\% guru menyatakan belum adanya buku panduan keterampilan koping, dan 54\% yang mengembangkan keterampilan koping di kelas melalui pembiasaan tetapi belum melalui pembelajaran. Dengan demikian, kepala sekolah perlu memfasilitasi kebutuhan guru dalam pengembangan pembelajaran keterampilan koping, dan orang tua perlu dilibatkan baik dalam pelatihan, memberikan pelaporan, serta membiasakan anak sesuai dengan arahan guru untuk mendukung pengembangan keterampilan koping anak. Guru pun perlu diberikan pelatihan agar mampu menerapkan pembelajaran keterampilan koping dengan lebih baik.

\section{UCAPAN TERIMA KASIH}

Segala puji bagi Allah Swt., atas berkat rahmatNya sehingga peneliti dapat menyelesaikan penelitian ini. Peneliti mengucapkan terima kasih kepada Prof. Dr. Edi Purwanta, M.Pd dan Dr. Suwarjo, M.Si. atas arahan dan bimbingannya secara komprehensif.

\section{DAFTAR PUSTAKA}

Beritagar, R. (2016). Jangan lupakan pendidikan anak usia dini. Beritagar.Id Merawat Indonesia. https://beritagar.id/artikel-amp/editorial/jangan-lupakan-pendidikananak-usia-dini

Berk, L. (2006). Child development (7 th). Pearso Allyn and Bacon.

Blazar, D., \& Kraft, M. A. (2017). Teacher and Teaching Effects on Students' Attitudes and Behaviors. Educational Evaluation and Policy Analysis, 39(1), 146-170. https://doi.org/10.3102/0162373716670260

Bronfenbrenner, U. (2004). Making human beings human bioecological perspectives on human development. Sage Publitions Ltd.

Campbell, J. P., \& Wiernik, B. M. (2015). The Modeling and Assessment of Work Performance. Annual Review of Organizational Psychology and Organizational Behavior, 2(April), 47-74. https:// doi.org/10.1146/annurev-orgpsych-032414-111427

Carver, C. S., \& Connor-Smith, J. (2010). Personality and coping. Annual Review of Psychology, 61, 679-704. https://doi.org/10.1146/annurev.psych.093008.100352

Chalmers, K., Frydenberg, E., \& Deans, J. (2011). An Exploration Into the Coping Strategies of Preschoolers: Implications for Professional Practice. Children Australia, 36(3), 120-127. https://doi.org/10.1375/jcas.36.3.120

Compas, B. E. (2009). Coping, regulation, and development during childhood and adolescence. New Directions for Child and Adolescent Development, 2009(124), 87-99. https://doi.org/10.1002/cd.245

Compas, B. E., Connor-Smith, J. K., Saltzman, H., Thomsen, A. H., \& Wadsworth, M. E. (2001). Coping with stress during childhood and adolescence: Problems, progress, and potential in theory and research. Psychological Bulletin, 127(1), 87-127. https://doi.org/10.1037/0033-2909.127.1.87

Denham, S. A., Bassett, H. H., \& Zinsser, K. (2012). Early childhood teachers as socializers of young children's emotional competence. Early Childhood Education Journal, 40(3), 137-143. https:/ / doi.org/10.1007/s10643-012-0504-2

Dewantara, K. H. (1977). Karya ki hajar dewantara. Majelis Luhur Persatuan Taman Siswa.

Dombro, A. ., Jablon, J. R., \& Stetson, C. (2011). Powerful Iiteractions. Young Children, 66(1), 12-16. https:// eric.ed.gov/?id=EJ930002

Douvlos, C. (2019). Bullying in preschool children. Psychological Thought, 12(1), 131-142. https://doi.org/10.5964/psyct.v12i1.284 
Durlak, J. A., Weissberg, R. P., Dymnicki, A. B., Taylor, R. D., \& Schellinger, K. B. (2011). The Impact of Enhancing Students' Social and Emotional Learning: A Meta-Analysis of School-Based Universal Interventions. Child Development, 82(1), 405-432. https://doi.org/10.1111/j.1467-8624.2010.01564.x

Dutta, M., Islam, S. F. S., Akhter, S. R., \& Ahmed, S. T. (2014). Supporting Young Children ' s Emotional Well-being in Classroom: Teachers ' Belief and Attitude. Bangladesh Education Journal, 13(2), 7-28. https://www.bafed.net/pdf/E_December 2014.930_1.pdf

Ferreira, M., Martinsone, B., \& Talic, S. (2020). Promoting sustainable social emotional learning at school through relationship-centered learning environment, teaching methods and formative assessment. Journal of Teacher Education for Sustainability, 22(1), 21-36. https:// doi.org/10.2478/jtes-2020-0003

Frydenberg, E., Deans, J., \& Liang, R. (2014). Families can do coping: Parenting skills in the early years. Children Australia, 39(2), 99-106. https:/ / doi.org/10.1017/cha.2014.7

Gartrell, D., \& Cairone, B. (2014). Fostering resilience teaching sosial-emotional skill. Young Children, 69(3), 92-93. https://doi.org/10.12968/chhe.2021.2.3.114

Graziano, P. A., Reavis, R. D., Keane, S. P., \& Calkins, S. D. (2007). The role of emotion regulation in children's early academic success. Journal of School Psychology, 45(1), 319. https:// doi.org/10.1016/j.jsp.2006.09.002

Grewal, D., Roggeveen, A. L., \& Nordfält, J. (2017). The Future of Retailing. Journal of Retailing, 93(1), 1-6. https:// doi.org/10.1016/j.jretai.2016.12.008

Hansen, C. C., \& Zambo, D. (2007). Loving and learning with wemberly and David: Fostering emotional development in early childhood education. Early Childhood Education Journal, 34(4), 273-278. https:/ / doi.org/10.1007/s10643-006-0124-9

Ho, J., \& Funk, S. (2018). Promoting young children's social and emotional health. Young Children, 73(1), 73-79. https://openlab.bmcc.cuny.edu/ece-110-lecture/wpcontent/uploads/sites/98/2019/12/Ho-Funk-2018.pdf

Hoffmann, J., \& Russ, S. (2012). Pretend play, creativity, and emotion regulation in children. Psychology of Aesthetics, Creativity, and the Arts, 6(2), 175-184. https://doi.org/10.1037/a0026299

Huffman, M. H. (2016). Advancing the Practice of Health Coaching. Workplace Health and Safety, 64(9), 400-403. https:/ / doi.org/10.1177/2165079916645351

Kong, F., Zhao, J., \& You, X. (2012). Social support mediates the impact of emotional intelligence on mental distress and life satisfaction in Chinese young adults. Personality and Individual Differences, 53(4), 513-517. https://doi.org/10.1016/j.paid.2012.04.021

Lin, Y. W., \& Bratton, S. C. (2015). A meta-analytic review of child-centered play therapy approaches. Journal of Counseling and Development, 93(1), 45-58. https:// doi.org/10.1002/j.1556-6676.2015.00180.x

Martani, W., \& Psikologi, F. (2012). Metode Stimulasi dan Perkembangan Emosi Anak Usia Dini. Jurnal Psikologi, 39(1), 112-120. https:// doi.org/10.22146/jpsi.6970

Masfuah, S., \& Rusilowati, A. (2011). Pembelajaran Kebencanaan Alam Dengan Model Bertukar Pasangan Bervisi Sets Untuk Menumbuhkan Kemampuan Berpikir Kritis Siswa. Jurnal Pendidikan Fisika Indonesia, 7(2), 115-120. https:// doi.org/10.15294/jpfi.v7i2.1083

Mcdermott, P. A., Rikoon, S. H., Waterman, C., Fantuzzo, J. W., Mcdermott, P. A., Rikoon, S. H., Waterman, C., Fantuzzo, J. W., Mcdermott, P. A., Rikoon, S. H., Waterman, C., \& Fantuzzo, J. W. (2019). The Preschool Learning Behaviors Scale: Dimensionality and External Validity in Head Start Paul. School Psychology Review, 41(1), 66-81. https:// doi.org/10.1080/02796015.2012.12087376

O'Conner, R., De Feyter, J., Carr, A., Luo, J. L., \& Romm, H. (2017). A Review of the Literature on Social and Emotional Learning for Students Ages 3-8: Characteristics of Effective 
Social and Emotional Learning Programs (Part 1 of 4). REL 2017-245. Regional Educational Laboratory Mid-Atlantic.

Röll, J., Koglin, U., \& Petermann, F. (2012). Emotion regulation and childhood aggression: Longitudinal associations. Child Psychiatry and Human Development, 43(6), 909-923. https://doi.org/10.1007/s10578-012-0303-4

Santrock, J. W. (2011). Life span development. perkembangan masa hidup. Erlangga.

Sotardi, V. A. (2018). Bumps in the Road: Exploring Teachers' Perceptions of Student Stress and Coping. Teacher Educator, 53(2), 208-228. https://doi.org/10.1080/08878730.2017.1422826

Taylor, E., Verhulst, F. C., Wong, J., \& Yoshida, K. (2020). Mental health and illness of children and adolescents. Springer. https:// doi.org/10.1007/978-981-10-2348-4

UNESCO. (2019). Transforming Education Conference for Humanity (TECH). https://mgiep.unesco.org/tech

WHO. (2015). World health statistics $2015 . \quad$ WHO. https:/ / reliefweb.int/sites/reliefweb.int/files/resources/9789240694439_eng.pdf 